\title{
To License or Not to License Reexamined: An Updated Report on State Statutes Regarding Private Investigators and Digital Examiners
}

Thomas Lonardo

Roger Williams University

Alan Rea

Western Michigan University

Doug White

Roger Williams University

Follow this and additional works at: https://commons.erau.edu/jdfsl

Part of the Computer Engineering Commons, Computer Law Commons, Electrical and Computer Engineering Commons, Forensic Science and Technology Commons, and the Information Security Commons

\section{Recommended Citation}

Lonardo, Thomas; Rea, Alan; and White, Doug (2015) "To License or Not to License Reexamined: An Updated Report on State Statutes Regarding Private Investigators and Digital Examiners," Journal of Digital Forensics, Security and Law: Vol. 10 : No. 1 , Article 4.

DOI: https://doi.org/10.15394/jdfsl.2015.1197

Available at: https://commons.erau.edu/jdfsl/vol10/iss1/4

This Article is brought to you for free and open access by the Journals at Scholarly Commons. It has been accepted for inclusion in Journal of Digital Forensics, Security and Law by an authorized administrator of Scholarly Commons. For more information, please contact commons@erau.edu.

(c)ADFSL 


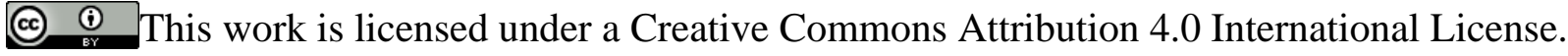

\title{
TO LICENSE OR NOT TO LICENSE REEXAMINED: AN UPDATED REPORT ON STATE STATUTES REGARDING PRIVATE INVESTIGATORS AND DIGITAL EXAMINERS
}

\author{
Thomas Lonardo \\ School of Justice Studies and Gabelli School of Business \\ Roger Williams University \\ One Old Ferry Road Bristol, RI 02809 \\ Phone: 401-254-3580 \\ E-mail: tlonardo@rwu.edu \\ Alan Rea ** \\ Haworth College of Business \\ Western Michigan University \\ 1903 West Michigan Avenue \\ Kalamazoo, MI 49008-5412 \\ Phone: 269-387-1444 \\ E-mail alan.rea@wmich.edu \\ Doug White \\ Cybersecurity and Networking \\ FANS Center, School of Justice Studies \\ Roger Williams University \\ One Old Ferry Road \\ Bristol, RI 02809 \\ Phone: 401-254-3165 \\ E-mail: dwhite@rwu.edu \\ ** Corresponding Author
}

\begin{abstract}
In this update to the 2012 year's study, the authors examine statutes that regulate, license, and enforce investigative functions in each US state. As before, the authors find that very few state statutes explicitly differentiate between Private Investigators and Digital Examiners. However, there is a small trend in which some states are changing definitions or moving to exempt DE from PI licensing requirements. We examine this trend as well as look at some additional information in terms of practicing attorney exemptions that may cloud the licensing waters.
\end{abstract}


(c) () This work is licensed under a Creative Commons Attribution 4.0 International License

As with the previous research studies (Lonardo et al., 2008, 2009, 2012) the authors contacted all state regulatory agencies where statutory language was not explicit, and as a result, set forth the various state approaches to professional Digital Examiner licensing. Our recommendation remains the same: states must differentiate between Private Investigator and Digital Examiner licensing requirements and oversight.

Keywords: Digital Examiner, Computer Forensics, State Statutes, Private Investigator, Licensing Requirements

\section{INTRODUCTION}

When we started researching the diverse state licensing requirements for digital examiners and private investigators we determined the need to distinguish between the two professions. Our research unearthed more confusion than clarification as states either worked to apply outdated PI licensing requirements to burgeoning technical digital forensics profession or ignored licensing them altogether (Lonardo et al., 2008).

In just over a year we found more states willing to respond to our queries - from 19 to 3 non-responses - as well as more effort by states to address the licensing issue (Lonardo et al., 2009). Unfortunately, states decided to combine PI and DE licensing requirements (19) with only four making a distinction between the professions. Only 15 states either excluded DEs from licensing or did not require PI or DE licensing (Lonardo et al., 2009). What we did take note of was the movement to define the DE role.

However, our latest study found that although states were working to define digital examiner definitions and subsequent roles, states still conflate the licensing of the two professions; this led to situations in which technicians without PI licenses could be found culpable for examining hard drives (Lonardo et al., 2012). This being said more, rather than fewer, states required digital examiners to be licensed private investigators (20) with the same additional four states making a distinction between the two professions in their licensing (Lonardo et al., 2012). Only 12 states either excluded DE from licensing or did not require PI or DE licensing (Lonardo et al., 2012). This is a reduction from previous years.

The shift in defining digital examiners yet still licensing them as private investigators led us along two paths:

To look elsewhere and determine where the increasing amount of digital evidence was being analyzed (Shavers, 2013). Were more PIs moving into the digital forensics field or are different professionals examining digital evidence?

To look at changes in state digital examiner licensing definitions or classifications from our last study (Lonardo et al., 2012). Our research shows some states changing definitions or moving to exempt DE from PI licensing requirements.

\section{THE PRACTICING ATTORNEY UMBRELLA}

Although digital evidence processing under an attorney's practice does not supersede state regulations for $\mathrm{PI} / \mathrm{DE}$ licensing in our opinion, it does muddy the waters somewhat because much of what a digital examiner does as it relates to legal proceedings occurs when the DE would likely work in tandem with an attorney. 
(c) () This work is licensed under a Creative Commons Attribution 4.0 International License.

As such, a review of the attorney exemption from licensing (if applicable) for those states where a PI license for DEs is believed to be required is important so that DEs are aware of the potential certification issues.

\subsection{Three Categories of Exemptions}

The categories of attorney exemptions generally fall into three categories: 1. exclusively limited to attorneys (Table 1); 2. attorneys and any employees exclusively working for the attorney (Table 2); and 3. attorneys, attorney's employees, or independent contractors working for the attorney (Table 3).

The first category is self-explanatory. Only the attorney is exempt from the licensing. Potential implications and complications come into play whether the DE would or should be allowed to practice in the context of a legal proceeding because in many cases this is where much of the DE's work would be conducted. In effect, an attorney can directly perform any investigation, including extraction of digital evidence, in preparation for a legal case/proceeding that a PI may undertake in the PI's normal course of their licensed profession.
However, if an attorney needs to review or have data extracted from a hard drive, email account, or any digital device he/she would most likely need to hire a digital forensics examiner. Even if the attorney is a skilled technician who can extract the digital evidence, the attorney would not be in a position to enter the digitally retrieved information as evidence since he/she extracted it and not a third party expert witness who can validate and "sponsor" such evidence at trial independently. Therefore, the value of the PI certification exemption from a digital evidence extraction and potential expert testimony perspective becomes greatly diminished in a trial's context.

If an attorney in these states needs DE services, his/her hiring choices are restricted to only those who have a PI license. The situation potentially precludes the attorney from hiring a DE who is highly regarded and possesses a particular area of technical expertise and proficiency if he/she is not a licensed PI. The result might compromise the attorney's case and result in a disservice to the attorney's client. In the end, the "direct attorney" PI license exemption, from a digital examination perspective, has little practical impact because an attorney would most likely hire a DE who possesses a PI license in order to have the strongest case for his/her client. 
(a) $\stackrel{0}{\text { iv }}$ This work is licensed under a Creative Commons Attribution 4.0 International License

Table 1

Exclusively Limited to Attorneys in their Practice of Law

\begin{tabular}{|c|l|}
\hline California & $\begin{array}{l}\text { An attorney-at-law in performing his or her duties as an attorney-at- } \\
\text { law. }\end{array}$ \\
\hline Florida & Any attorney in the regular practice of her or his profession. \\
\hline Hawaii & $\begin{array}{l}\text { An attorney-at-law in performing the attorney's duties as such } \\
\text { attorney-at-law. §463-13 }\end{array}$ \\
\hline Iowa & $\begin{array}{l}\text { An attorney licensed to practice in Iowa, while performing duties as an } \\
\text { attorney. } \mathbf{8 0 A . 2 ( 4 )}\end{array}$ \\
\hline Louisiana & An attorney-at-law licensed to practice in this state and his employees. \\
\hline Maine & $\begin{array}{l}\text { An attorney admitted to practice law in the State acting in a } \\
\text { professional capacity. }\end{array}$ \\
\hline Michigan & $\begin{array}{l}\text { An attorney admitted to practice in this state in performing his or her } \\
\text { duties as an attorney-at-law. }\end{array}$ \\
\hline Minnesota & $\begin{array}{l}\text { An attorney-at-law while performing the duties of an attorney-at-law or } \\
\text { an investigator employed exclusively by an attorney or a law firm } \\
\text { engaged in investigating legal matters. }\end{array}$ \\
\hline South Carolina & An attorney-at-law while in the performance of his duties. \\
\hline Tennessee & An attorney-at-law in good standing and licensed to practice law. \\
\hline
\end{tabular}

The second classification might be some cause for concern. We question whether this means a full-time digital examiner for a particular law firm might be exempt from licensing. If the person performing digital examinations is an employee then that person may perform the examination as a result of the exemption. Whether a person is an "employee" (versus sub-contractor) has been subject to numerous tests under federal case law interpretation of various federal statutes. The IRS follows the "common Law" classification based on the totality of the circumstances in determining the degree of control over the person performing the services by the employer:

Under common-law rules, anyone who performs services for you is your employee if you can control what will be done and how it will be done. This is so even when you give the employee freedom of action. What matters is that you have the right to control the details of how the services are performed. (IRS, 2014)

The IRS uses a 20-factor analysis to apply this test. In other circumstances the "Economic Realities" test is applied. In the Economic Realities test the degree of ongoing economic dependence on the employer is reviewed and depending on the statute in question, courts--to include some state courts-utilize a hybrid of the Common Law and Economic Realities test (Houseman, 1999; Muhl, 2002).

Ultimately, the practitioner needs to review the relevant state law regarding how an employee is defined. For all intents, the practical implication would be that unless an attorney or law firm has an employee who is a $\mathrm{DE}$, they would need to hire a DE who is licensed under the state certification statute. 
(9) (-) This work is licensed under a Creative Commons Attribution 4.0 International License.

Table 2

Attorneys and Employees Exclusively Working for the Attorney

\begin{tabular}{|c|c|}
\hline Arizona & $\begin{array}{l}\text { A practicing attorney involved in a case for which the attorney has been } \\
\text { retained or a person employed under an employee-employer relationship } \\
\text { with a practicing attorney, in the employee's performance of duties related } \\
\text { to a case for which the attorney has been retained. }\end{array}$ \\
\hline Arkansas & 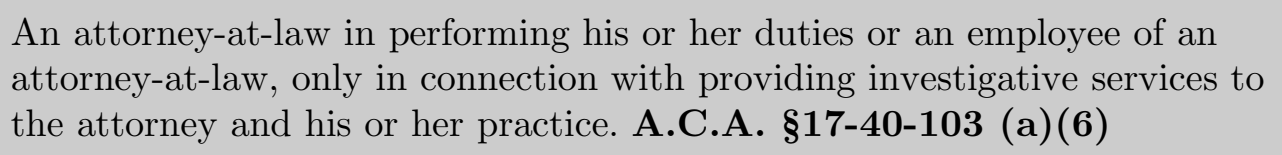 \\
\hline Indiana & $\begin{array}{l}\text { An attorney or employee of an attorney to the extent that the person is } \\
\text { engaged in investigative matters incident to the delivery of professional } \\
\text { services that constitute the practice of law. }\end{array}$ \\
\hline Maryland & $\begin{array}{l}\text { A lawyer, while performing any activity that relates to the lawyer's regular } \\
\text { practice of law in the State; to an individual who, as a regular part-time or } \\
\text { full-time employee of a lawyer, provides services that relate to the lawyer's } \\
\text { regular practice of law in the State. }\end{array}$ \\
\hline Missouri & $\begin{array}{l}\text { An attorney performing duties as an attorney, or an attorney's paralegal or } \\
\text { employee retained by such attorney assisting in the performance of such } \\
\text { duties or investigation on behalf of such attorney. }\end{array}$ \\
\hline $\begin{array}{l}\text { New } \\
\text { Hampshire }\end{array}$ & $\begin{array}{l}\text { Attorneys, and employees of their law firms acting as their agents, } \\
\text { exercising legal rights to investigate on behalf of their clients }\end{array}$ \\
\hline New York & $\begin{array}{l}\text {...nor shall anything in this article contained be construed to affect in any } \\
\text { way attorneys or counselors at law in the regular practice of their } \\
\text { profession, but such exemption shall not inure to the benefit of any } \\
\text { employee or representative of such attorney or counselor at law who is not } \\
\text { employed solely, exclusively and regularly by such attorney or counselor at } \\
\text { law. Article } 7 \S 83\end{array}$ \\
\hline Oregon & $\begin{array}{l}\text { An attorney admitted to practice law in this state performing the } \\
\text { attorney's duties as an attorney. } \\
\text { A legal assistant or paralegal engaged in activity for which the person is } \\
\text { employed by an attorney admitted to practice law in this state. }\end{array}$ \\
\hline Tennessee & $\begin{array}{l}\text { An employee of a single attorney or single law firm who is acting within the } \\
\text { employee's scope of employment for the attorney or law firm. }\end{array}$ \\
\hline Wisconsin & $\begin{array}{l}\text {...to attorneys, law students or law school graduates employed by an } \\
\text { attorney. }\end{array}$ \\
\hline
\end{tabular}


(c) () This work is licensed under a Creative Commons Attribution 4.0 International License

This category would definitely cause some Georgia's statute as it relates to a "Bona Fide issues. For example, would a digital examiner working on a consulting basis be included? Moreover, there are potential issues with Legal Assistant" and North Dakota's "legal assistant" (Table 3).

Table 3

Attorneys, Employees of the Attorney or Independent Contractors Working for the Attorney

\begin{tabular}{|l|l|}
\hline Ohio & $\begin{array}{l}\text { Attorneys at law or any expert hired by an attorney-at-law for } \\
\text { consultation or litigation purposes. }\end{array}$ \\
\hline Georgia & $\begin{array}{l}\text { An attorney-at-law or a bona fide legal assistant in performing his or } \\
\text { her duties. \$43-38-14(3) }\end{array}$ \\
\hline North Dakota & $\begin{array}{l}\text { Any attorneys or counselors at law in the regular practice of their } \\
\text { profession and any paralegal or legal assistant employed by an attorney } \\
\text { or law firm when the attorney or law firm retains complete } \\
\text { responsibility for the work product of the paralegal or legal assistant. }\end{array}$ \\
\hline Tennessee & $\begin{array}{l}\text { A consultant when the person is retained by an attorney or appointed } \\
\text { by a court to make tests, conduct experiments, draw conclusions, } \\
\text { render opinions or make diagnoses, where those services require the use } \\
\text { of training or experience in a technical, scientific or social science field. }\end{array}$ \\
\hline West Virginia & $\begin{array}{l}\text { Attorneys or counselors-at-law or any employee or representative of } \\
\text { such attorney or counselor. }\end{array}$ \\
\hline
\end{tabular}

From a statutory interpretation perspective under the Georgia statute, the term "Bona Fide Legal Assistant," and North Dakota's "legal assistant" may be open to interpretation that could include an independent consultant. However, we urge caution in accepting this view. The traditional role of a legal assistant is one who works exclusively for a lawyer or law firm in assisting the attorney or law firm in various legal matters such as research, drafting and review of legal documents and other legal administrative support and not performing forensic analysis.

In fact, in looking to the United States Department of Labor Statistics (DOLS), the description of a Legal Assistant and Paralegal are treated virtually the same. As the DOLS website states "Paralegals and legal assistants are found in all types of organizations, but most work for law firms, corporate legal departments, and government agencies. They usually work full time, and overtime is sometimes needed to meet deadlines" (BLS, 2014).

Ultimately, when a practitioner is hired by an attorney to perform DE duties that are precluded by the state PI statute in question, it is important that the practitioner not only determine how the state distinguishes the "employee" vs. sub-contractor status but also look how the state courts strictly enforce expert usage by attorneys in court proceedings as well as in what context the PI statute applies in the administration of justice.

\section{PI/DE STATE CLASSIFICATION CHANGES}

The question of attorney/employee/consultant exemptions most likely will lead to more confusion than clarification. However, digital examiners need to be aware of state response and statute changes that might cause licensing 


\section{@) (-) This work is licensed under a Creative Commons Attribution 4.0 International License}

questions where there were none prior. We list all state statues in Table 4, but note important changes since our previous study (Lonardo et al., 2012) below.

Table 4

State Licensing Statutes

\begin{tabular}{|c|c|c|}
\hline State & $\begin{array}{l}\text { Authors' Belief } \\
\text { (S) By Statute } \\
\text { (O) By Opinion }\end{array}$ & Statute \\
\hline Alabama & (S) No PI Licensing Requirement & $\S 34-25 \mathrm{~B}-24$ et seq \\
\hline Alaska & No PI Licensing Statute & NA \\
\hline Arizona & (O) PI Licensing Requirement & $\S 24-32-2401$ et seq \\
\hline Arkansas & (O) PI Licensing Requirement & $\S 17-2-40$ et seq \\
\hline California & $\begin{array}{l}\text { (O) Licensing Requirement - Ltd. } \\
\text { Exclusion }\end{array}$ & $\S 11.3-7512$ et seq \\
\hline Colorado & $\begin{array}{l}\text { (S) Licensing Requirement - Ltd. } \\
\text { Exclusion }\end{array}$ & $\S 12-58.5-101$ et seq \\
\hline Connecticut & (O) No PI Licensing Requirement & $\begin{array}{l}\text { Chapter } 534 \text { C.G.S } 29-152 \mathrm{u} \text { et } \\
\text { seq See also declaratory ruling } \\
8 / 4 / 08\end{array}$ \\
\hline Delaware & (S) No PI Licensing Requirement & $\S 24-12-1301-1341$ \\
\hline $\begin{array}{l}\text { District of } \\
\text { Columbia }\end{array}$ & (O) PI Licensing Requirement & $\S 47-2839$ \\
\hline Florida & (O) PI Licensing Requirement & $\S 493.6201$ et seq \\
\hline Georgia & (O) PI Licensing Requirement & $\S 43-38-1-17$ et seq \\
\hline Hawaii & (O) No PI Licensing Requirement & $\begin{array}{l}\S 463-1 \text { et seq and } \S 16-97-1-50 \\
\text { et seq }\end{array}$ \\
\hline Idaho & No PI Licensing Statute & NA \\
\hline Illinois & (S) No PI Licensing Requirement & 225 ILCS 447 et seq \\
\hline Indiana & (O) PI Licensing Requirement* & IC $25-0.5-3-19$ et seq \\
\hline Iowa & (O) PI Licensing Requirement & 80A.1-18 et seq \\
\hline Kansas & (O) No PI Licensing Requirement & $\S 75-7 \mathrm{~b} 01$ et seq \\
\hline Kentucky & (O) PI Licensing Requirement * & KRS §329A.010 et seq \\
\hline Louisiana & $\begin{array}{l}\text { (S) Limited No Licensing } \\
\text { Requirement }\end{array}$ & La. R.S. $§ 37: 3500$ et seq \\
\hline Maine & $\begin{array}{l}\text { (O) Licensing Requirement - Ltd. } \\
\text { Exclusion }\end{array}$ & $\S 32-89-8101$ et seq \\
\hline Maryland & (O) PI Licensing Requirement & $\S 13.101$ et seq \\
\hline Massachusetts & (O) PI Licensing Requirement* & $\S 147-22$ et seq \\
\hline Michigan & (S) PI Licensing Requirement & $\S 338.821$ et seq \\
\hline Minnesota & (O) PI Licensing Requirement & 326.32 et seq \\
\hline Mississippi & No PI Licensing Statute & NA \\
\hline Missouri & $\begin{array}{l}\text { (S) Licensing Requirement - Ltd. } \\
\text { Exclusion }\end{array}$ & $\S 324.1100$ et seq \\
\hline Montana & (S) No PI Licensing Requirement & $\S 37-60-101$ et seq \\
\hline
\end{tabular}


(ब) (-) This work is licensed under a Creative Commons Attribution 4.0 International License

\begin{tabular}{|c|c|c|}
\hline State & $\begin{array}{l}\text { Authors' Belief } \\
\text { (S) By Statute } \\
\text { (O) By Opinion }\end{array}$ & Statute \\
\hline Nebraska & (O) PI Licensing Requirement & $\S 71-3201$ et seq \\
\hline Nevada & (S) No PI Licensing Requirement & $\S N R S 648.005$ et seq \\
\hline New Hampshire & (O) PI Licensing Requirement & $\S 106-\mathrm{F}: 1$ et seq \\
\hline New Jersey & (O) PI Licensing Requirement * & $\S 45: 19-9$ et seq \\
\hline New Mexico & (O) PI Licensing Requirement * & $\S 61-27 \mathrm{~B}-1$ et seq \\
\hline New York & (O) PI Licensing Requirement & $\S 7-70$ et seq \\
\hline North Carolina & (S) No PI Licensing Requirement & $\S 74 \mathrm{C}-1$ et seq \\
\hline North Dakota & $\begin{array}{l}\text { (O) Licensing Requirement - Ltd. } \\
\text { Exclusion }\end{array}$ & $\S 43-30-01$ et seq \\
\hline Ohio & $\begin{array}{l}\text { (S) Licensing Requirement - Ltd. } \\
\text { Exclusion }\end{array}$ & $\S 4749.01$ et seq \\
\hline Oklahoma & (O) PI Licensing Requirement & $\S 59-42 \mathrm{a}-1750.02$ et seq \\
\hline Oregon & (O) PI Licensing Requirement * & $\S 703.401$ et seq \\
\hline Pennsylvania & $\begin{array}{l}\text { (S) Licensing Requirement by } \\
\text { County }\end{array}$ & NA \\
\hline Rhode Island & (S) No PI Licensing Requirement & $\S 5-5-1$ et seq \\
\hline South Carolina & (O) PI Licensing Requirement & $\S 40-18-20$ et seq \\
\hline South Dakota & No PI Licensing Statute & NA \\
\hline Tennessee & $\begin{array}{l}\text { (O) Licensing Requirement - Ltd. } \\
\text { Exclusion }\end{array}$ & $\S 62-35-01$ et seq \\
\hline Texas & (S) PI Licensing Requirement & $\S 1702.001$ et seq \\
\hline Utah & (O) No PI Licensing Requirement & $\S 53-9-101$ et seq \\
\hline Vermont & (O) No PI Licensing Requirement & §26-59-3151 et seq \\
\hline Virginia & (S) No PI Licensing Requirement & $\S 9.1-138$ et seq \\
\hline Washington & (S) No PI Licensing Requirement & RCW $\S 18.165 .010$ et seq \\
\hline West Virginia & $\begin{array}{l}\text { (O) Licensing Requirement - Ltd. } \\
\text { Exclusion }\end{array}$ & $\S 30-18-1$ \\
\hline Wisconsin & $\begin{array}{l}\text { (S) Licensing Requirement - Ltd. } \\
\text { Exclusion }\end{array}$ & $\S 440.26$ \\
\hline Wyoming & No PI Licensing Statute & NA \\
\hline
\end{tabular}

* No Response

\subsection{Changes in Classifications}

A troubling change from our last study occurred with states that previously rendered an opinion as to the statute's applicability and now either declined to render an opinion (in such cases a default position of a license requirement is noted if there are no applicable exemptions) or the opinion varied from the previous opinion.
In Oklahoma the regulatory body of private investigators--the Council on Law Enforcement Education and Training (CLEET)--previously stated the PI licensing did not apply to Digital Examiners. However CLEET's legal counsel has responded that the attorney who rendered the previous response for CLEET is no longer with the council. He indicated further that he does not give legal opinions as to the applicability of certain 
(c) () This work is licensed under a Creative Commons Attribution 4.0 International License

statues since he represents the council and by extension the council's director. This moves Oklahoma from a no licensing requirement for Digital Examiners opinion to an unknown (Lonardo et al., 2012).

Indiana has not responded to our inquiry update. The response in the past has been to decline an opinion (Lonardo et al., 2008).

States, such as Oklahoma and Indiana, which do not render an opinion, create a "trap for the unwary." Digital Examiners who work in these states that believe in good faith that they would not be subject to the PI licensing requirements may later discover through a violation citation that a PI license is required. We recommend caution.

Conversely, potential practitioners may decide to go through the time and expense to qualify under a PI statute to ultimately find out they do not need a PI license. Withholding such guidance creates confusion and uncertainty, and is problematic for digital examiners who may want to practice in these states. As always, we recommend more statue and licensing clarification from these states.

\subsection{Amended Statutes to Exempt Digital Examiners}

Since our last report on certification findings, three states have clarified their statutes to exempt Digital Examiners either directly or by virtue of the nature of the exemption (Table 5).
Exempting Digital Examiners is a move in the correct direction when it comes to licensing requirements that conflate the $\mathrm{PI} / \mathrm{DE}$ role. However, we argue that DE licensing is desirable as long as the licensing is distinguished from PI licensing and the DE licensing statutes include reasonable and meaningful criteria with an eye towards protecting the public as well as the integrity of the profession.

\subsection{Limited Exemptions to Licensing}

We have amended some of our findings to move certain state positions to the "Limited Exclusion" classification. The states with limited exemptions include those mentioned in Table 3 "Attorneys, Employees of the Attorney or Independent Contractors Working for the Attorney." For consistency and ease of reference this classification is included in Table 6 .

In many cases the determination as to whether a state PI license is required is dependent on a number of factors including: (1) the specific function(s) and tasks performed by the DE; (2) who has hired the DE and for what purpose; (3) the status as an expert in the eyes off a court; and (4) the specific inclusion or exclusion by the states PI statue. The DE practitioner must identify their engagement status and seek legal guidance if there is any question in this regard. 
(a) (0) This work is licensed under a Creative Commons Attribution 4.0 International License.

Table 5

Exempt Digital Examiners

\begin{tabular}{|l|l|}
\hline \multirow{5}{*}{ Alabama } & $\begin{array}{l}\text { SB } 172 \text { specifically exempts according to section (9): Any individual engaged in the } \\
\text { following:(a) Computer or digital forensic services (b) The acquisition, review, or analysis } \\
\text { of digital or computer-based information for evidentiary or other purposes or to provide } \\
\text { expert testimony before any court, board, officer or investigating committee. (c) Network } \\
\text { or system vulnerability testing, including network scans and risk assessment and analysis } \\
\text { of computers connected to a network. }\end{array}$ \\
\hline Illinois & $\begin{array}{l}\text { 225 ILCS 447/15-5 A person, firm, or other entity engaged in providing computer } \\
\text { forensics services so long as the person, firm, or other entity does not hold himself or } \\
\text { herself out to be a private detective. For the purposes of this item (5), "computer } \\
\text { forensics services" means a branch of forensic science pertaining to the recovery and } \\
\text { analysis of electronically stored information. }\end{array}$ \\
\hline \multirow{5}{*}{ Nevada } & $\begin{array}{l}\text { NRS } \mathbf{6 4 8 . 0 1 2} \text { "Private investigator" defined. "Private investigator" means any person } \\
\text { who for any consideration engages in business or accepts employment to furnish, or } \\
\text { agrees to make or makes any investigation for the purpose of obtaining, including, } \\
\text { without limitation, through the review, analysis and investigation of computerized data } \\
\text { not available to the public, information with reference to: } \\
\text { 4. A crime or tort that has been committed, attempted, threatened or suspected, except } \\
\text { an expert witness or a consultant who is retained for litigation or a trial, or } \\
\text { in anticipation of litigation or a trial, and who performs duties and tasks } \\
\text { within his or her field of expertise that are necessary to form his or her } \\
\text { opinion; (emphasis added) }\end{array}$ \\
\hline
\end{tabular}

Table 6

Limited Exclusions

\begin{tabular}{|l|l}
\hline California & Not required for data extraction: Required if inquiries or communications to anyone.
\end{tabular} An attorney licensed to practice law in this state, an employee of a licensed attorney, or

Colorado $\quad$ a person under contract to perform paralegal services for a licensed attorney. 12-58.5105c

\begin{tabular}{l|l} 
Ohio & Attorneys at law or any expert hired by an attorney-at-law for consultation or litigation
\end{tabular} purposes

\begin{tabular}{|c|c|}
\hline Georgia & $\begin{array}{l}\text { An attorney-at-law or a bona fide legal assistant in performing his or her duties. §43- } \\
\mathbf{3 8 - 1 4 ( 3 )}\end{array}$ \\
\hline Louisiana & Not required for "technical experts". \\
\hline Maine & Required for data extraction: Not required for offering Expert Testimony. \\
\hline Missouri & Expert witness exception. \\
\hline North Dakota & $\begin{array}{l}\text { Any attorneys or counselors at law in the regular practice of their profession and any } \\
\text { paralegal or legal assistant employed by an attorney or law firm when the attorney or } \\
\text { law firm retains complete responsibility for the work product of the paralegal or legal } \\
\text { assistant. } \\
\text { Not required for data extraction: Required if inquiries or communications to anyone. }\end{array}$ \\
\hline Oregon & $\begin{array}{l}\text { 407 Expert witness exception. The licensing requirement of ORS } \mathbf{7 0 3 . 4 0 5} \text { does not } \\
\text { apply to a person while the person is:(1) Providing testimony in a court as an expert } \\
\text { under ORS 40.410; or (2) Conducting investigations or reviews or engaging in other } \\
\text { activities in preparation for providing testimony in a court as an expert under ORS } \\
\text { 40.410. }\end{array}$ \\
\hline Tennessee & Tot required for attorneys, employees of attorneys or consultants hired by attorneys. \\
\hline Test & ttornevs or counselors-at-law or any emplovee or representative of such attorney or \\
\hline
\end{tabular}


@) (-) This work is licensed under a Creative Commons Attribution 4.0 International License 4. CONCLUSION

The trend examined in our prior research holds true: states continue to approach the issue of licensing DEs under PI statutes in varied approaches and regulatory interpretations of statutes. As before, we have relied on documented findings such as statues and written (email) regulatory opinions and feedback. However, a major challenge lies with our reliance on regulatory authorities to provide "unofficial" or official feedback responses as to how they handle the licensing issue under their relevant PI statute.

For the vast majority of inquiries the appropriate authority has been responsive and accommodating in communicating their interpretation of the regulatory boundaries set forth in their respective statutes. In some cases it is quite clear as the statute provides straight forward guidance. However, in a few cases--as noted above--the regulatory body either declined feedback on the statute's applicability or simply referred us back to the PI statue, leaving us to make our own interpretation. In these cases if it is not absolutely clear in the statute we determined a PI license is required.
Ultimately, a total of 18 states rendered an opinion as to the applicability of the statute. Not surprising 14 of the 18 opinions indicated a PI license is required. Some regulatory authorities indicated that even if the statute could lean either way they would err on the side of caution and require a license. This degree of subjectivity would be alleviated if there were clearer and unambiguous statutes dealing specifically with DE licensing.

Finally an area of concern and one for our future research is the state or federal court prospective regarding whether there is a conflict between the rules of evidence dealing with the allowance of expert witnesses (particularly DEs) vs. the PI licensing requirements. This issue is particularly acute where, as is the case with many PI statutes, a PI license is required in order to testify before a court or tribunal as an expert supporting evidence. This paper is limited to the statutory requirements only and as such no research or findings either way has been determined, but is planned for a future paper. 
(c) () This work is licensed under a Creative Commons Attribution 4.0 International License REFERENCES

Bureau of Labor Statistics [BLS] (2014). Retrieved December 24, 2014 from http://www.bls.gov/ooh/Legal/Paralegal s-and-legal-assistants.htm\#tab-1

Houseman, S. (1990). Flexible Staffing Arrangements, A Report on Temporary Help, On-Call, Direct-Hire Temporary, Leased, Contract Company, and Independent Contractor Employment in the United States. Department of Labor 9.1. Retrieved December 27 from http://www.dol.gov/oasam/programs/his tory/herman/reports/futurework/confere nce/staffing/9.1_contractors.htm

Internal Revenue Service [IRS] (2014). Retrieved December 182014 from http://www.irs.gov/Businesses/SmallBusinesses-\&-Self-Employed/EmployeeCommon-Law-Employee

Lonardo, T., White, D. \& Rea, A. (2008). To License or Not to License: An Examination of State Statutes Regarding Private Investigators and Digital Examiners. Journal of Digital Forensics, Security and Law, 3(3).

Lonardo, T., White, D. \& Rea, A. (2009). To License or Not to License Revisited: An Examination of State Statutes Regarding Private Investigators and Digital Examiners. Journal of Digital Forensics, Security and Law, 4(3).

Lonardo, T., White, D. \& Rea, A. (2012). To License or Not to License Updated: An Examination of State Statutes Regarding Private Investigators and Digital Examiners. Journal of Digital Forensics, Security and Law, $7(3)$.

Muhl, C. (2002). Who Is an Employee? Determining Independent Contractor Status. Bureau of Labor Statistics, Monthly Labor Review, January
2002(11). Retrieved December 27, 2014 from

http://www.bls.gov/opub/mlr/2002/01/a rt1full.pdf

Shavers, B. (2013). Placing the Suspect Behind the Keyboard: Using Digital Forensics and Investigative Techniques to Identify Cybercrime Suspects $\left(1^{\text {st }}\right.$ ed). Syngress Publishing. 